\title{
Cerebrovascular disease is associated with the risk of mortality in coronavirus disease 2019
}

\author{
Ying Wang ${ }^{1} \cdot$ Li Shi $^{1} \cdot$ Yadong Wang $^{2} \cdot$ Guangcai Duan $^{1} \cdot$ Haiyan Yang ${ }^{1}$ (D)
}

Received: 10 May 2020 / Accepted: 21 June 2020 / Published online: 30 June 2020

(C) Fondazione Società Italiana di Neurologia 2020

Dear Editor,

Recently, the paper by Wang et al. demonstrated a significant relationship between cerebrovascular disease and patients with severe coronavirus disease 2019 (COVID-19) $(\mathrm{OR}=3.89,95 \% \mathrm{CI}: 1.64-9.22, P=0.002)$ in a metaanalysis based on three published studies [1]. To our knowledge, there have been several published articles reporting the association between cerebrovascular disease and the risk of mortality in COVID-19 patients [2-6]. However, the conclusions are not consistent. Therefore, it is required to clarify the association of the cerebrovascular disease with the risk of mortality in COVID-19 patients by using a systematically quantitative meta-analysis.

Relevant studies were extracted by systematic retrieval of PubMed, Web of Science, and China National Knowledge Infrastructure (CNKI) up to date to April 30, 2020. The searching terms used were as follows: "coronavirus" or "COVID-19" or "SARS-CoV-2" or "2019-nCoV" and "clinical" and "mortality" or "outcome." Duplicate results were removed. All studies were evaluated for eligibility by two independent reviewers (Ying Wang and Li Shi). Inclusion criteria are the following: (1) studies reporting extractable data on a past history of cerebrovascular disease in laboratoryconfirmed COVID-19 patients and (2) compared patients between survivors and non-survivors. Exclusion criteria are as follows: (1) reviews and case reports and (2) non-survivor subgroup was not included in the study. Odds ratio (OR) with its $95 \%$ confidence intervals (CI) was applied to estimate the combined effects. Heterogeneity was evaluated with the $I^{2}$

Ying Wang and Li Shi contributed equally to this work.

Haiyan Yang

yhy@zzu.edu.cn

1 Department of Epidemiology, School of Public Health, Zhengzhou University, No. 100 of Science Avenue, Zhengzhou 450001, China

2 Department of Toxicology, Henan Center for Disease Control and Prevention, Zhengzhou 450016, China test. A fixed-effects model was selected to compute the combined effects if there was no obvious heterogeneity among studies $\left(I^{2} \leq 50 \%\right)$. Otherwise, a random-effects model was applied [7]. The possibility of publication bias was checked by using Egger's test and Begg's test [8]. Sensitivity analysis was carried out by excluding studies successively [9]. The statistical analysis was carried out using the Stata 11.2 (StataCorp, College Station, TX), and the $P$ value $<0.05$ was considered to be statistically significant.

We found a total of 966 records, and 741 remained after the removal of duplicates. Forty-two records remained after reading the title and abstract. After reading the full text, we excluded 34 studies that did not report a past history of cerebrovascular disease and finally included eight articles for our meta-analysis. Included studies grouped into survival and non-survival groups (six articles), recovered and non-survival groups (one article), and discharged and non-survival groups (one article). The essential characteristics are presented in Table 1.

Seven studies compared cerebrovascular disease in nonsurvival vs. survival patients with a total of 1374 confirmed COVID-19 patients including 392 (28.5\%) non-survival cases. A past history of cerebrovascular disease was reported in 126 patients (9.2\%), of whom $70(55.6 \%)$ patients were classified as non-survivors. Besides, one study by Chen et al. individually provided a hazard ratio (HR) $(\mathrm{HR}=4.28$, 95\% CI: 1.07-8.94) for cerebrovascular disease and mortality of COVID-19 patients [10].

Our meta-analysis showed that cerebrovascular disease was significantly associated with an increased risk of mortality in COVID-19 patients on the basis of a fixed-effects model $(\mathrm{OR}=4.78,95 \%$ CI: 3.24-7.03, $P<0.001)$ (Fig. 1a). Heterogeneity was not observed presently $\left(I^{2}=22.4 \%, P=\right.$ 0.251 ). The sensitivity analysis indicated that the combined OR did not change significantly after deleting each study one by one. Although the combined OR was declined (OR = 3.319, 95\% CI: $1.98-5.57, P<0.001)$ after deleting Li Juyi et al.'s study [5], the result still indicated that cerebrovascular 
Table 1 Characteristics of the included studies

\begin{tabular}{|c|c|c|c|c|c|c|c|c|c|}
\hline \multirow[t]{2}{*}{ Authors } & \multirow[t]{2}{*}{ Location } & \multirow[t]{2}{*}{ Group } & \multirow[t]{2}{*}{ Samples } & \multicolumn{3}{|c|}{ Non-survival patients } & \multicolumn{3}{|c|}{ Survival patients } \\
\hline & & & & Age & Male & $\begin{array}{l}\text { Cerebrovascular/ } \\
\mathrm{n}\end{array}$ & Age & Male & $\begin{array}{l}\text { Cerebrovascular/ } \\
\mathrm{n}\end{array}$ \\
\hline $\begin{array}{l}\text { Yang Xiaobo et al. } \\
\text { (PMID: } \\
\text { 32105632) }\end{array}$ & China & $\begin{array}{l}\text { Survival vs. } \\
\text { non-survival }\end{array}$ & 52 & $64.6(11.2)$ & $21(66 \%)$ & $7 / 32$ & $51.9(12.9)$ & $14(70 \%)$ & $0 / 20$ \\
\hline $\begin{array}{l}\text { Cao Jianlei et al. } \\
\text { (PMID: } \\
\text { 32239127) }\end{array}$ & China & $\begin{array}{l}\text { Survival vs. } \\
\text { non-survival }\end{array}$ & 102 & $72(63-81)$ & $13(76 \%)$ & $3 / 17$ & $53(47-66)$ & $40(47 \%)$ & $3 / 85$ \\
\hline $\begin{array}{l}\text { Ruan Qiurong et al. } \\
\text { (PMID: } \\
\text { 32253449) }\end{array}$ & China & $\begin{array}{l}\text { Discharged vs. } \\
\text { non-survival }\end{array}$ & 150 & $67(15-81)$ & $49(72 \%)$ & $7 / 68$ & $50(44-81)$ & $53(65 \%)$ & $5 / 82$ \\
\hline $\begin{array}{l}\text { Li Juyi et al. (PMID: } \\
32324209 \text { ) }\end{array}$ & China & $\begin{array}{l}\text { Survival vs. } \\
\text { non-survival }\end{array}$ & 362 & $72(64.5-82)$ & $50(65 \%)$ & $37 / 77$ & $65(57.5-71)$ & $139(48 \%)$ & $31 / 285$ \\
\hline $\begin{array}{l}\text { Chen Tao et al. } \\
\text { (PMID: } \\
\text { 32217556) }\end{array}$ & China & $\begin{array}{l}\text { Recovered vs. } \\
\text { non-survival }\end{array}$ & 274 & $68(62-77)$ & $83(73 \%)$ & $4 / 113$ & $51(37-66)$ & $88(55 \%)$ & $0 / 161$ \\
\hline $\begin{array}{l}\text { Wang Lang et al. } \\
\text { (PMID: } \\
\text { 32240670) }\end{array}$ & China & $\begin{array}{l}\text { Survival vs. } \\
\text { non-survival }\end{array}$ & 339 & $76(70-83)$ & $39(60 \%)$ & $10 / 65$ & $68(64-74)$ & $127(46 \%)$ & $11 / 274$ \\
\hline $\begin{array}{l}\text { Chen Ruchong et al. } \\
\text { (PMID: } \\
\text { 32304772) }\end{array}$ & China & $\begin{array}{l}\text { Survival vs. } \\
\text { non-survival }\end{array}$ & 1950 & $69(51-86)$ & $30(60 \%)$ & $6 / 50$ & NR & NR & NR \\
\hline $\begin{array}{l}\text { Tomlins Jennifer } \\
\text { et al. (PMID: } \\
\text { 32353384) }\end{array}$ & UK & $\begin{array}{l}\text { Survival vs. } \\
\text { non-survival }\end{array}$ & 95 & $77(72-85)$ & $12(60 \%)$ & $2 / 20$ & $74(56-82)$ & $48(64 \%)$ & $6 / 75$ \\
\hline
\end{tabular}

All values are $n(\%)$, mean (SD), and median (IQR)

NR not reported

a

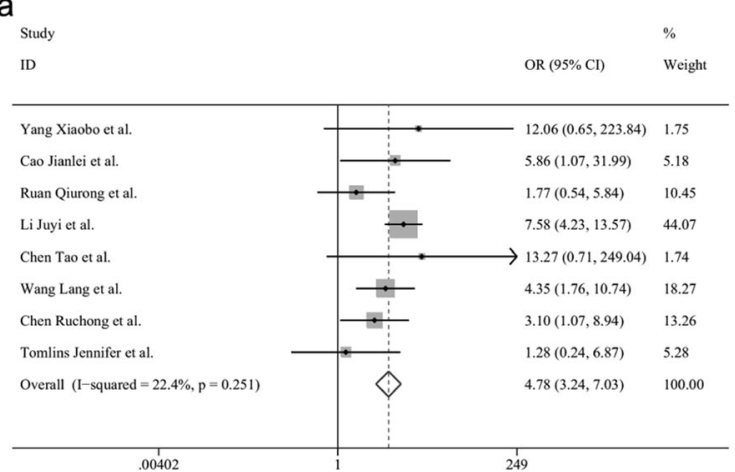

C

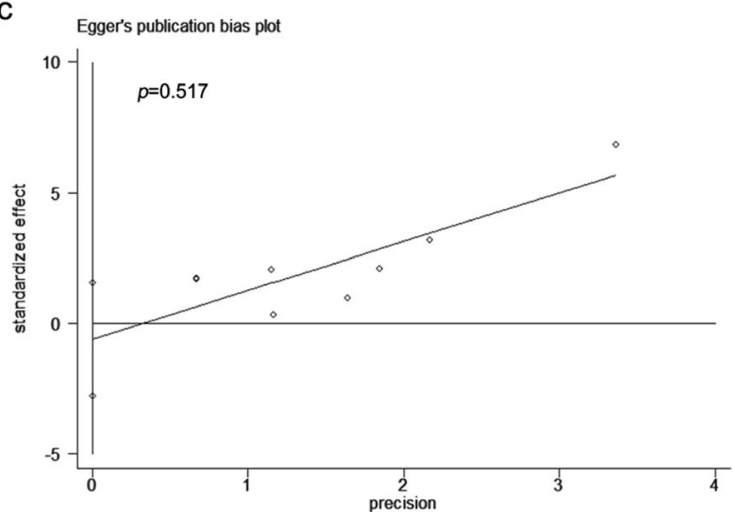

b

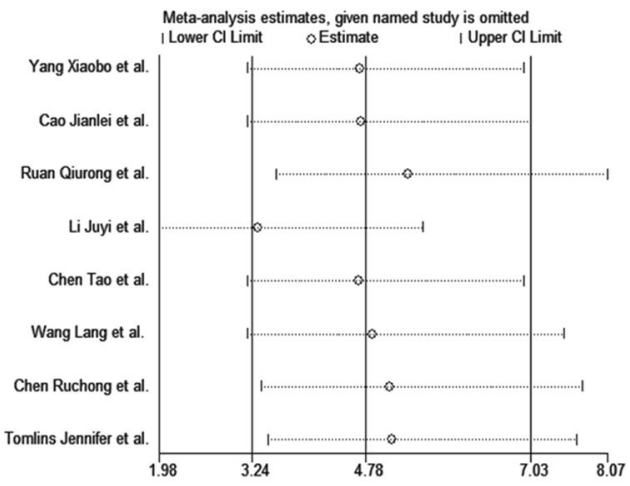

d

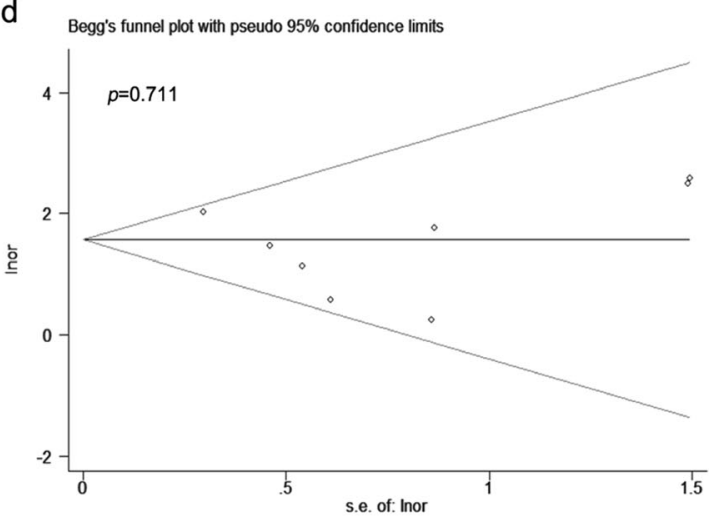

Fig. 1 Odds ratio (OR) with its 95\% confidence intervals (CI) for cerebrovascular disease (a), sensitivity analysis for cerebrovascular disease (b), publication bias assessment: Egger's test (c) and Begg's test (d) 
disease was associated with an increased risk of mortality in COVID-19 patients (Fig. 1b). Hence, we can consider our result to be robust. The results of Egger's test $(P=0.517)$ (Fig. 1c) and Begg's test $(P=0.711)$ (Fig. 1d) indicated there was no publication bias presently.

To our knowledge, a previous meta-analysis by Aggarwal et al. did not observe a significant association between a past history of cerebrovascular disease and the risk of mortality in COVID-19 patients based on two published studies $(\mathrm{OR}=$ 2.33, 95\% CI: 0.77-7.04) [11]. However, in our present meta-analysis based on eight published studies, the cerebrovascular disease was identified to be significantly associated with an increased risk of mortality in COVID-19 patients. Some patients with COVID-19 have neurological symptoms, such as headache, anosmia, dysgeusia, dizziness, and impaired consciousness [12]. There is evidence that SARSCoV-2 has neuro-invasive abilities and might spread from the respiratory system to the central nervous system $[13,14]$. COVID-19 may also predispose cerebrovascular diseases due to inflammation, hypoxia, and diffuse intravascular coagulation [15]. Thus, clinicians should strengthen the monitoring of COVID-19 patients with the cerebrovascular disease.

This study has several limitations. Firstly, except for one article from the UK, most of the articles came from China. Secondly, some patients had more than one coexisting illness in our included studies. Hence, our conclusion needs to be treated with caution and further analyses including more studies are needed to verify our findings.

Funding information This work was supported by a grant from the National Natural Science Foundation of China (grant number 81973105).

\section{Compliance with ethical standards}

Conflict of interest The authors declare that they have no conflict of interest.

Ethics approval Not Applicable.

\section{References}

1. Wang B, Li R, Lu Z, Huang Y (2020) Does comorbidity increase the risk of patients with COVID-19: evidence from meta-analysis. Aging 12(7):6049-6057. https://doi.org/10.18632/aging.103000

2. Yang X, Yu Y, Xu J, Shu H, Xia J, Liu H, Wu Y, Zhang L, Yu Z, Fang M, Yu T, Wang Y, Pan S, Zou X, Yuan S, Shang Y (2020) Clinical course and outcomes of critically ill patients with SARSCoV-2 pneumonia in Wuhan, China: a single-centered, retrospective, observational study. Lancet Respir Med 8:475-481. https:// doi.org/10.1016/s2213-2600(20)30079-5
3. Ruan Q, Yang K, Wang W, Jiang L, Song J (2020) Clinical predictors of mortality due to COVID-19 based on an analysis of data of 150 patients from Wuhan, China. Intensive Care Med 46:1-3. https://doi.org/10.1007/s00134-020-05991-x

4. Tomlins J, Hamilton F, Gunning S, Sheehy C, Moran E, Macgowan A (2020) Clinical features of 95 sequential hospitalised patients with novel coronavirus 2019 disease (COVID-19), the first UK cohort. J Inf Secur. https://doi.org/10.1016/j.jinf.2020.04.020

5. Li J, Wang X, Chen J, Zhang H, Deng A (2020) Association of renin-angiotensin system inhibitors with severity or risk of death in patients with hypertension hospitalized for coronavirus disease 2019 (COVID-19) infection in Wuhan, China. JAMA Cardiol. https://doi.org/10.1001/jamacardio.2020.1624

6. Wang L, He W, Yu X, Hu D, Bao M, Liu H, Zhou J, Jiang H (2020) Coronavirus disease 2019 in elderly patients: characteristics and prognostic factors based on 4-week follow-up. J Inf Secur 80: 639-645. https://doi.org/10.1016/j.jinf.2020.03.019

7. Higgins JP, Thompson SG, Deeks JJ, Altman DG (2003) Measuring inconsistency in meta-analyses. BMJ 327(7414):557560. https://doi.org/10.1136/bmj.327.7414.557

8. Egger M, Davey Smith G, Schneider M, Minder C (1997) Bias in meta-analysis detected by a simple, graphical test. BMJ 315(7109): 629-634. https://doi.org/10.1136/bmj.315.7109.629

9. Wu S, Jiang J, Liu J, Wang X, Gan Y, Tang Y (2017) Meta-analysis of SIRT1 expression as a prognostic marker for overall survival in gastrointestinal cancer. Oncotarget. 8(37):62589-62599. https:// doi.org/10.18632/oncotarget. 19880

10. Chen R, Liang W, Jiang M, Guan W, Zhan C, Wang T, Tang C, Sang L, Liu J, Ni Z, Hu Y, Liu L, Shan H, Lei C, Peng Y, Wei L, Liu Y, Hu Y, Peng P, Wang J, Liu J, Chen Z, Li G, Zheng Z, Qiu S, Luo J, Ye C, Zhu S, Liu X, Cheng L, Ye F, Zheng J, Zhang N, Li Y, He J, Li S, Zhong N (2020) Risk factors of fatal outcome in hospitalized subjects with coronavirus disease 2019 from a nationwide analysis in China. Chest. https://doi.org/10.1016/j.chest.2020.04. 010

11. Aggarwal G, Lippi G, Michael Henry B (2020) Cerebrovascular disease is associated with an increased disease severity in patients with coronavirus disease 2019 (COVID-19): a pooled analysis of published literature. Int J Stroke 15:385-389. https://doi.org/10. $1177 / 1747493020921664$

12. Wu Y, Xu X, Chen Z, Duan J, Hashimoto K, Yang L, Liu C, Yang C (2020) Nervous system involvement after infection with COVID19 and other coronaviruses. Brain Behav Immun. https://doi.org/10. 1016/j.bbi.2020.03.031

13. Li YC, Bai WZ, Hashikawa T (2020) The neuroinvasive potential of SARS-CoV2 may play a role in the respiratory failure of COVID-19 patients. J Med Virol 92:552-555. https://doi.org/10. $1002 /$ jmv. 25728

14. Calcagno N, Colombo E, Maranzano A, Pasquini J, Keller Sarmiento IJ, Trogu F, Silani V (2020) Rising evidence for neurological involvement in COVID-19 pandemic. Neurol Sci 41:1-3. https://doi.org/10.1007/s10072-020-04447-w

15. Klok FA, Kruip M, van der Meer NJM, Arbous MS, Gommers D, Kant KM, Kaptein FHJ, van Paassen J, Stals MAM, Huisman MV, Endeman H (2020) Incidence of thrombotic complications in critically ill ICU patients with COVID-19. Thromb Res 191:145-147. https://doi.org/10.1016/j.thromres.2020.04.013

Publisher's note Springer Nature remains neutral with regard to jurisdictional claims in published maps and institutional affiliations. 